\title{
Effect of Lifestyle Modification with Metformin on Serum Chemerin Concentration of Metabolic Syndrome Subjects
}

\author{
Dharma Lindarto $^{1^{*}, \text { Brama Ihsan Sazli }}{ }^{2}$ \\ ${ }^{1,2}$ Department of Internal Medicine, Faculty of Medicine, Universitas Sumatera Utara
}

\begin{abstract}
Chemerin is adipokine that plays an important role in macrophage infiltration into adipose tissue and may contribute to inflammation development and insulin resistance. This study aimed to determine the effect of lifestyle modification with and without metformin on chemerin in metabolic syndrome. Forty-five metabolic syndrome subjects (IDF-2005) were randomly assigned to one of the two groups: placebo group $(n=22)$ and metformin group $(n=23)$. Both groups underwent a 12-week lifestyle modification (diet and moderate aerobic-exercise). Only 40 participants (placebo group $n=20$ and metformin group $n=20$ ) completed the survey whereas 5 participants dropped out of the study. After their lifestyle was modified, body weight, BMI, WC, and chemerin decreased significantly $(\mathrm{p}<0.001)$ in both groups. Moreover, there was a significant difference between both groups in body weight, BMI, and WC $(\mathrm{p}<0.05)$ but not for chemerin. Thus, lifestyle modification with metformin improved BW, BMI, WC on metabolic syndrome, and there was no decrease significantly of chemerin between placebo and metformin groups. Further investigations should be done to confirm the effect of lifestyle modification and metformin on chemerin after an extended follow-up period.
\end{abstract}

Keyword: Lifestyle modification, Metabolic syndrome, Chemerin

\begin{abstract}
Abstrak. Chemerin adalah adipokin yang memainkan peran penting dalam infiltrasi makrofag ke dalam jaringan adiposa dan dapat berkontribusi pada perkembangan peradangan dan resistensi insulin. Penelitian ini bertujuan untuk mengetahui pengaruh modifikasi gaya hidup dengan dan tanpa metformin pada chemerin pada sindrom metabolik. Empat puluh lima subyek sindrom metabolik (IDF-2005) secara acak ditugaskan ke salah satu dari dua kelompok: kelompok plasebo $(n=22)$ dan kelompok metformin $(n=23)$. Kedua kelompok menjalani modifikasi gaya hidup 12 minggu (diet dan olahraga aerobik sedang). Hanya 40 peserta (kelompok plasebo $n=20$ dan kelompok metformin $n=20$ ) menyelesaikan survei sedangkan 5 peserta keluar dari penelitian. Setelah gaya hidup mereka dimodifikasi, berat badan, BMI, WC, dan chemerin menurun secara signifikan $(p<0,001)$ pada kedua kelompok. Selain itu, ada perbedaan yang signifikan antara kedua kelompok dalam berat badan, BMI, dan WC $(p<0,05)$ tetapi tidak untuk chemerin. Dengan demikian, modifikasi gaya hidup dengan metformin meningkatkan $B W, B M I, W C$ pada sindrom metabolik, dan tidak ada penurunan chemerin yang signifikan antara kelompok plasebo dan metformin.Investigasi lebih lanjut harus dilakukan untuk
\end{abstract}

\footnotetext{
*Corresponding author at: Faculty of Medicine, Universitas Sumatera Utara, H. Adam Malik Hospital, Jalan Bunga Lau No 17, Medan 20136, Indonesia
}

E-mail address: dharma@usu.ac.id 
mengkonfirmasi pengaruh modifikasi gaya hidup dan metformin pada chemerin setelah periode tindak lanjut yang diperpanjang.

Kata Kunci: Modifikasi Gaya Hidup, Sindrom Metabolik, Chemerin

Received [date month year] | Revised [date month year] | Accepted [xx Month xxxx]

\section{Introduction}

Metabolic syndrome represents a combination of cardiometabolic risk factors and determinants including central adiposity, insulin resistance, glucose intolerance, dyslipidemia, non-alcoholic fatty liver disease, and hypertension. The prevalence of metabolic syndrome increases rapidly worldwide as a result of the continuous obesity epidemic. It will also have a risk on the global incidence of cardiovascular disease and T2D [1]. Adiposity has been identified as an important endocrine organ that does not only store energy but also regulates energy homeostasis and metabolism [2].

Chemerin was recently found as an adipokine, and its expression increased in obesity state [3,4]. Several specific functions of chemerin are including regulation of specific immune cell migration [4,5], anti-inflammatory effects on macrophages [6], and regulation of adipogenesis [5]. Previously, a significant association has been identified between circulating chemerin levels and characteristics of the metabolic syndrome in a relatively small sample of human subjects from Mauritius [3]. Bozaoglu et al, measured circulating chemerin levels in human subjects and found that plasma chemerin concentrations were strongly associated with BMI, plasma triglycerides, and blood pressure [7]. Metformin treatment decreases serum chemerin in women with PCOS [8].

Physical inactivity is known as the risk factor of type 2 diabetes mellitus (T2DM) [9], and aerobic training has been shown to reduce adiposity and insulin resistance in obese adults [10]. There has been no previous report about lifestyle modification induces changes in chemerin concentrations in metabolic syndrome, which may provide a link between obesity and insulin resistance.

Lifestyle modification against overweight, physical inactivity, and atherogenic diet has been recommended as a basic in the management of metabolic syndrome [11]. However, only lifestyle modification is often unable to achieve clinically meaningful weight loss [12].

Metformin, a biguanide oral hypoglycemic agent has been shown to reduce weight, hyperinsulinemia, and hyperglycemia in adult patients with T2D [13]. Metformin also has been recently suggested to attenuate the insulin-sensitizing effect of exercise [14], inhibition of platelet aggregation, antioxidant activity, weight reduction, an effect on lipid parameters: total cholesterol, high density lipoprotein cholesterol (HDL-C), low-density lipoprotein cholesterol 
(LDL-C), triglycerides (TG), and arterial hypertension [15,16]. Metformin can be given safely to euglycemic patients because it does not induce hypoglycemia [17].

Therefore, the aim of this study was to assess the effect of lifestyle modification with metformin on chemerin in metabolic syndrome.

\section{Method}

The research subjects were recruited in H. Adam Malik Hospital, Medan, Indonesia. From 184 obese nurses $(\mathrm{BMI} \geq 25)$, only 45 subjects were diagnosed with metabolic syndrome (IDF2005) and agreed to involve in lifestyle modification for 12 weeks. IDF-2005 guidelines for diagnosis of metabolic syndrome were used, namely central obesity with a WC of $\geq 90 \mathrm{~cm}$ for men and $\geq 80 \mathrm{~cm}$ for women (Asian population), and any two of the following four factors: (1) triglyceride $\geq 150 \mathrm{mg} / \mathrm{dl}$ or specific treatment for lipid abnormality; (2) HDL-C (men $<40 \mathrm{mg} / \mathrm{dl}$ and women $<50 \mathrm{mg} / \mathrm{dl}$ ) or specific treatment for lipid abnormality; (3) hypertension $\geq 130 / 85$ $\mathrm{mmHg}$ or treatment of previously diagnosed hypertension; and (4) FBS $\geq 100 \mathrm{mg} / \mathrm{dl}$ or previously diagnosed T2D $[18,19]$. They were assigned randomly to either the placebo group $(n=22)$ or metformin group $(n=23)$.

All subjects gave their fully informed consent before participated in the study. The local Ethical Committee has approved the study. We excluded subjects who were smokers, had cardiovascular diseases or any other major illnesses or were taking medications that could affect the laboratory test results. Before and during the study, trained health nurses and participants discussed the lifestyle modification programs including diet and exercise. To facilitate behavioral change, each participant received a leaflet and diary to record their behavioral performance, diet, physical activity, WC, and body weight [BW] monitored by phone. Participants attended a follow-up meeting every week to confirm how the participants had complied with the targeted behaviors and checked whether the participants had experienced any health and safety problems related to behavioral changes including the side effect of drugs.

\subsection{Anthropometric}

Heights in meters $(\mathrm{m})$ and weight in kilograms $(\mathrm{kg})$ were measured, and BMI was also calculated as the weight in kilograms divided by the square of the height in meters. For the Asian population, BMI < 18.5 is classified as underweight, BMI 18.5-22.9 is classified as normal, BMI 23-24.9 is classified as overweight, BMI 25-29.9 is classified as obese I, and BMI $\geq 30.0$ is classified as obese II [18]. The waist circumference (WC) was measured midway between the uppermost border of the iliac crest and the lower border of the costal margin (rib cage), and Asian values (male $\geq 90 \mathrm{~cm}$; female $\geq 80 \mathrm{~cm}$ ) [18]. The exercise program consisted of a moderate aerobic exercise for at least 3 times per week (30 minutes each) [20]. The aerobic exercise was supervised by a physiotherapist at each training session. The exercise group 
performed a warm-up exercise for $5 \mathrm{~min}$, followed by the main exercise for $20 \mathrm{~min}$, and relaxation exercise for $5 \mathrm{~min}$ at the end of the exercise period [21].

\subsection{Diet}

Between 0 and 12-week period throughout the study, all subjects followed a weight maintenance diet (55-60\% carbohydrate, $15-20 \%$ protein, and 20-25\% fat) [21]. All subjects were free to consume and choose the food according to their dietary habits and from the list of food replacement.

\subsection{Blood Pressure and Blood Sample Analysis}

Blood pressure was measured twice after a 10-min rest with the mercury sphygmomanometer and averaged. After overnight fasting and collection, blood samples were centrifuged for $15 \mathrm{~min}$ while plasma and serum containing tubes were stored at - $200 \mathrm{C}$ until analysis. Blood glucose levels were measured by photometer autoanalyzer Modular P 800, plasma HDL-C and LDL-C were measured by the Architect Ci 8200 (Abbott, USA), triglyceride was measured by GPOPAP methods of Architect, hs-CRP was measured by sensitive immunoassay (Siemens Medical Solution Inc, IL, USA) of Immulite 1000 , HbA1c was measured by high-performance liquid chromatographic (HPLC) of the Bio-Rad D 10, and chemerin was measured by Mediagnost ELISA E-102 (Sandwich-Assay).

\section{Statistical Analysis}

Data were presented as mean \pm SD. Normality assumption of the placebo group and metformin group data was evaluated and confirmed using Shapiro-Wilk in each group. Differences between and within each data of the placebo group and metformin group were tested using an independent sample t-test and dependent t-test. However, the abnormal data were tested using the Mann-Whitney $\mathrm{U}$ test and Wilcoxon test. Two-sided p-values of $<0.05$ were considered as statistically significant. The data were analyzed using SPSS software.

\section{Results}

Of the 45 participants at the baseline, 40 participants (placebo group, $n=20$; metformin group, $\mathrm{n}=20$ ) completed in the 12 -week survey, whereas 5 participants ( 2 participants from the placebo group and 3 participants from the metformin group) dropped out of the study.

In Table 1, there was no significant difference in the baseline characteristics of the two groups. 
Table 1 Clinical Characteristics of Placebo and Metformin Groups on Metabolic Syndrome Subjects

\begin{tabular}{|c|c|c|c|}
\hline Variable & $\begin{array}{l}\text { Placebo group } \\
n=22\end{array}$ & $\begin{array}{l}\text { Metformin } \\
\text { group } \\
\mathrm{n}=23\end{array}$ & $\mathrm{p}^{\mathrm{a}}$ \\
\hline n (F/M) & $17 / 5$ & $20 / 3$ & \\
\hline Age (yr) & $40.41 \pm 5.61$ & $42.91 \pm 5.62$ & 0.142 \\
\hline BW (kg) & $76.98 \pm 11.64$ & $80.53 \pm 14.72$ & 0.374 \\
\hline BMI $\left(\mathrm{kg} / \mathrm{m}^{2}\right)$ & $32.11 \pm 4.09$ & $34.03 \pm 5.76$ & 0.206 \\
\hline $\mathrm{WC}(\mathrm{cm})$ & $95.40 \pm 7.41$ & $97.23 \pm 10.95$ & 0.927 \\
\hline SBP (mmHg) & $123.18 \pm 11.29$ & $125.21 \pm 19.74$ & 0.567 \\
\hline DBP $(\mathrm{mmHg})$ & $82.00 \pm 9.99$ & $80.65 \pm 10.69$ & 0.247 \\
\hline $\begin{array}{l}\text { HDL-C } \\
(\mathrm{mg} / \mathrm{dl})\end{array}$ & $45.72 \pm 8.48$ & $48.34 \pm 15.47$ & 0.918 \\
\hline TG (mg/dl) & $150.40 \pm 51.05$ & $152.00 \pm 63.87$ & 0.974 \\
\hline FBG (mg/dl) & $85.27 \pm 11.98$ & $86.69 \pm 10,06$ & 0.351 \\
\hline PPG (mg/dl) & $115.72 \pm 11.98$ & $104.21 \pm 21.40$ & 0.401 \\
\hline $\begin{array}{l}\text { hs-CRP } \\
\text { (mg/dl) }\end{array}$ & $3.45 \pm 2.47$ & $3.83 \pm 2.34$ & 0.467 \\
\hline $\begin{array}{l}\text { Chemerin } \\
(\mathrm{ng} / \mathrm{mL})\end{array}$ & $344.09 \pm 104.58$ & $345.15 \pm 83.90$ & 0.970 \\
\hline
\end{tabular}

BW: body weight; BMI: Body Mass Index; CRP: C-reactive protein; DBP: Diastolic

Blood Pressure: FBS: fasting Blood Sugar; PPG: Postprandial Glucose; SBP: Systolic

Blood Pressure; TG: Triglyceride; WC: Waist Circumference; PPG: Postprandial glucose. ${ }^{\text {aBased }}$ on an independent $t$-test.

In Table 2, After 12 weeks of lifestyle modification, there was decrease significantly on BW, BMI, WC, SBP, and chemerin in both groups. There was no decrease significantly of chemerin on both groups.

Table 2 Clinical Characteristics of Placebo and Metformin Groups after 12-Week Follow-Up for both Groups of Metabolic Syndrome Subjects

\begin{tabular}{|c|c|c|c|c|c|c|c|c|c|}
\hline \multirow[t]{2}{*}{ Variable } & \multicolumn{4}{|c|}{$\begin{array}{l}\text { Placebo group } \\
(n=20)\end{array}$} & \multicolumn{4}{|c|}{$\begin{array}{l}\text { Metformin group } \\
(\mathrm{n}=20)\end{array}$} & \multirow[t]{2}{*}{$\mathrm{P}^{\mathrm{d}}$} \\
\hline & Baseline & At 12-week & $\begin{array}{l}\text { Differ } \\
\text { ence }^{a}\end{array}$ & $\mathrm{P}^{\mathrm{b}}$ & Baseline $^{a}$ & At 12 -week & $\begin{array}{l}\text { Differ } \\
\text { ence }^{a}\end{array}$ & $\mathrm{P}^{\mathrm{c}}$ & \\
\hline $\begin{array}{l}\text { Weight } \\
(\mathrm{kg})\end{array}$ & $77.6 \pm 11.0$ & $75.2 \pm 10.8$ & -2.3 & $0.001 * *$ & $81.4 \pm 14.6$ & $77.4 \pm 14.5$ & -3.9 & $0.001 * *$ & $0.001 * *$ \\
\hline $\begin{array}{l}\text { BMI } \\
\left(\mathrm{kg} / \mathrm{m}^{2}\right)\end{array}$ & $32.1 \pm 4.1$ & $30.9 \pm 4.1$ & -1.1 & $0.001 * *$ & $34.2 \pm 5.6$ & $32.4 \pm 5.6$ & -1.8 & $0.001 * *$ & $0.002 * *$ \\
\hline $\mathrm{WC}(\mathrm{cm})$ & $95.7 \pm 7.3$ & $89.9 \pm 7.5$ & -5.8 & $0.001 * *$ & $97.9 \pm 11.5$ & $91.8 \pm 10.7$ & -6.2 & $0.001 * *$ & $0.047 *$ \\
\hline $\begin{array}{l}\text { SBP } \\
(\mathrm{mmHg})\end{array}$ & $123.5 \pm 11.4$ & $114.0 \pm 8.2$ & -9.5 & $0.007 * *$ & $127.0 \pm 20.3$ & $112.8 \pm 8.5$ & -14.3 & $0.001 * *$ & 0.231 \\
\hline $\begin{array}{l}\mathrm{DBP} \\
(\mathrm{mmHg})\end{array}$ & $82.2 \pm 10.5$ & $69.0 \pm 5.5$ & -31.8 & $0.001 *$ & $80.6 \pm 11.0$ & $67.5 \pm 7.2$ & -13.3 & $0.001 * *$ & 0.300 \\
\hline $\begin{array}{l}\text { HDL-C } \\
(\mathrm{mg} / \mathrm{dl})\end{array}$ & $46.4 \pm 8.5$ & $45.3 \pm 10.0$ & -1.1 & 0.628 & $48.9 \pm 16.4$ & $46.5 \pm 9.8$ & -2.4 & 0.653 & 0.103 \\
\hline $\begin{array}{l}\mathrm{TG} \\
(\mathrm{mg} / \mathrm{dl})\end{array}$ & $147.5 \pm 50.5$ & $153.3 \pm 67.9$ & 5.8 & 0.634 & $152.3 \pm 66.9$ & $149.0 \pm 102.4$ & -3.3 & 0.147 & 0.285 \\
\hline FBS & $83.4 \pm 10.6$ & $91.7 \pm 20.64$ & 8.3 & $0.001 *$ & $84.9 \pm 8.9$ & $87.7 \pm 10.7$ & 2.8 & 0.305 & $0.039 *$ \\
\hline
\end{tabular}


$(\mathrm{mg} / \mathrm{dl})$

PPG

(mg/dl)

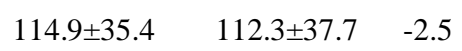

0.717

$105.1 \pm 22$.

$102.3 \pm 19.3$

$-2.8$

0.491

CRP

(mg/dl)

$3.6 \pm 2.5$

$3.0 \pm 2.2$

$-0.6$

$0.048 *$

$3.9 \pm 2.4$

$3.5 \pm 1.9$

$-0.6$

0.327

0.482

Chemerin

(ng/mL)

$339.5 \pm 106.6 \quad 225.5 \pm 43.7 \quad-113.9 \quad 0.001 * * \quad 339.9 \pm 82.9 \quad 226.5 \pm 46.1 \quad-113.9 \quad 0.001 * *$

BMI: Body Mass Index; CRP: C-reactive protein; DBP: Diastolic Blood Pressure: FBS: Fasting Blood Sugar; PPG; SBP: Systolic

Blood Pressure; TG: Triglyceride; WC: Waist Circumference; 2h-PPG: 2 hour-Postprandial glucose.

${ }^{a}$ Difference between the baseline and 12-week follow-up surveys

${ }^{\mathrm{b}}$ Difference between the baseline and 12-week follow-up surveys in the Placebo group, based on a dependent $t$-test.

${ }^{\mathrm{c}}$ Difference between the baseline and 12-week follow-up surveys in the Metformin group, based on a dependent $t$-test.

${ }^{\mathrm{d}} \Delta$ Difference between the Placebo group and Metformin group after the 12-week follow-up surveys, based on an independent $t$-test.

$* P<0.05, * * P<0.01$

\section{Discussion}

Adipose tissue is an active organ which secretes many metabolically important proteins known as adipokines [22]. Some of these adipokines have important functions in insulin resistance and cardiovascular complications with central or visceral obesity [23]. A recent systematic review of literature promotes a dose-response effect of aerobic exercise on visceral adiposity, but the ability of exercise to reduce visceral adipose tissue was less strenuous in those with metabolic disorders [24]. Thus, it remains unclear whether a dose-response of exercise on central adiposity is also consistent in metabolic syndrome. Nevertheless, regular exercise has an important role in the abdominal fat loss during weight maintenance and can avoid weight gain in those who have successfully lost weight [25]. Chemerin may have a role in the metabolic syndrome and may be an independent promising adipokine marker.

The study results of Saremi et al. showed that chemerin levels decreased significantly after body weight reduction (particularly visceral fat) in overweight and obese males after 12-week of aerobic training [26]. Similar results were recently presented in a large-scale epidemiological study from Mauritius [3].

According to these studies, lifestyle modification decreased BW, BMI, WC, DBP, and chemerin significantly in the placebo group and metformin group, whereas FBS and CRP only decreased significantly in the placebo group. However, there was no more effect of metformin on chemerin.

Plasma CRP concentration is known to be a key index of systemic inflammation. Few previous studies have reported the effect of exercise training on CRP levels. Mattusch et al. found a significant reduction in CRP levels after nine months of marathon training in 12 athletes [27]. Furthermore, Smith et al. also reported lower CRP levels in 43 volunteers after six months of exercise training. Based on these studies, chemerin decreased more significantly than CRP, and the future chemerin might replace the position of CRP as the key index of systemic inflammation [28]. Thus, lifestyle modification with metformin improved BW, BMI, WC, and chemerin on metabolic syndrome. There was no decrease significantly of chemerin between placebo and metformin groups. However, the limitation of the study was the small sample size and a short duration of the study. 


\section{Conclusion}

Lifestyle modification with metformin improved BW, BMI, WC on metabolic syndrome, and there was no significant decrease of chemerin between placebo and metformin groups. Further investigations should be done to confirm the effect of lifestyle modification and metformin on chemerin after an extended follow-up period.

\section{Acknowledgments}

The authors gratefully acknowledge that the present research is supported by Ministry of Research and Technology and the Higher Education Republic of Indonesia, Research and Community Service, Universitas Sumatera Utara.

\section{Conflict of Interests}

The authors declare that there is no conflict of interests regarding the publication of this paper

\section{REFERENCES}

[1] Bruce KD and Byrne CD. The metabolic syndrome: common origins of a multifactorial disorder. Postgrad Med. 2009;85:614-21.

[2] Rosen ED, Spiegelman BM. Adipocytes as regulators of energy balance and glucose homeostasis. Nature. 2006;444:847-53.

[3] Bozaoglu K, Bolton K, McMillan J, Zimmet P, Jowett J, Collier G, et al. Chemerin is a novel adipokine associated with obesity and metabolic syndrome. Endocrinology. 2007;148:4687-94.

[4] Goralski KB, McCarthy TC, Hanniman EA, Zabel BA, Butcher EC, Parlee SD, et al. Chemerin, a novel adipokine that regulates adipogenesis and adipocyte metabolism. J Biol Chem. 2007;282:28175-88.

[5] Zabel BA, Silverio AM, Butcher EC. Chemokine-like receptor-1 expression and chemerindirected chemotaxis distinguish plasmacytoid from myeloid dendritic cells in human blood. J Immunol. 2005b;174:244-51.

[6] Cash JL, Hart R, Russ A, Dixon JP, Colledge WH, Doran J. Synthetic chemerin-derived peptides suppress inflammation through ChemR-23. J Exp Med. 2008;205:767-75.

[7] Bozaoglu K, Segal D, Shields KA, Cummings N, Curran JE, Comuzzie AG, et al. Chemerin is associated with metabolic syndrome phenotypes in a Mexican-American population. J Clin Endocrinol Metab 2009; 94:3085-8.

[8] Tan BK, Chen J, Farhatullah S, Tan BK, Chen J, Farhatullah S, et al. Insulin and Metformin Regulate et al. Insulin and Metformin Regulate Circulating and Adipose Tissue Chemerin. Diabetes. 2009;58:1971-7.

[9] Venables MC, Jeukendrup AE. Physical inactivity and obesity: links with insulin resistance and type 2 diabetes mellitus. Diabetes Metab Res Rev. 2009;25:S18-23.

[10]O'Leary VB, Marchetti CM, Krishnan RK, Stetzer BP, Gonzalez F, Kirwan JP. Exerciseinduced reversal of insulin resistance in obese elderly is associated with reduced visceral fat. J Appl Physiol. 2006;100:1584-9.

[11]Eckel RH, Grundy SM, Zimmet PZ. The metabolic syndrome. Diagnosis and Management of the Metabolic Syndrome. Lancet. 2005;365:1415-28.

[12]Miller WC, Koceja DM, Hamilton EJ. A meta-analysis of the past 25 years of weight loss research using diet, exercise or diet plus exercise intervention. Int J Obes Relat Metab Disord. 1997;21:941-7.

[13]UKPDS. Effect of intensive blood-glucose control with metformin on complications in overweight patients with type 2 diabetes (UKPDS 34). UK prospective diabetes study group. Lancet .1998; 352:854-65.

[14]Sharoff CG, Hagobian TA, Malin SK, Chipkin SR, Yu H, Hirshman MF, et al. Combining 
short-term metformin treatment and one bout of exercise does not increase insulin action in insulin-resistant individuals. Am J Physiol Endocrinol Metab. 2010;298:E815-E23.

[15]Glueck CJ, Fontaine RN, Wang P, Subbiah MT, Weber K, Illig E, et al. Metformin reduces weight, centripetal obesity, insulin, leptin, and low-density lipoprotein cholesterol in nondiabetic, morbidly obese subjects with body mass index greater than 30 . Metabolism. 2001;50:856-61.

[16]Wulffele MG, Kooy A, de Zeeuw D, Stehouwer, Gansevoort. The effect of metformin on blood pressure, plasma cholesterol and triglycerides in type 2 diabetes mellitus: a systematic review. J of Internal Medicine. 2004; 256:1-14.

[17]Pasquali R, Gambineri A, Biscotti D, Vicennati V, Gagliardi L,Colitta et al. Effect of longterm treatment with metformin added to hypocaloric diet on body composition, fat distribution, and androgen and insulin levels in abdominally obese women with and without the polycystic ovary syndrome. J Clin Endocrinol Metab. 2000;85:2767-74.

[18]WHO Expert Consultation. Appropriate-body mass index for Asian populations and its implications for policy and intervention strategies. Lancet. 2004;363:157-63.

[19] Grundy SM, Cleeman JI, Daniels SR, Donato KA, Eckel RH, Franklin BA, et al. Diagnosis and management of the metabolic syndrome. An American Heart Association/National Heart, Lung, and Blood Institute Scientific Statement. Executive summary. Cardiol Rev 2005; 13:322-7.

[20]Misra A, Misra R, Wijesuriya M. The metabolic syndrome in South Asians. In: Mohan V, Rao HR, Gundu HR, editors. Type 2 diabetes in South Asians: Epidemiology, risk factors and prevention. New Delhi, India: Jaypee Brothers. 2006;pp.76-96.

[21]Perkeni. Consensus of Management and Prevention of Type 2 Diabetes Mellitus in Indonesia, 2015. Endocrine Association of Indonesia.

[22]Lau C, Toft U, Tetens I, Richelsen B, Jorgensen T, Bosch-Jhansen K, et al. Association between dietary glycemic index, glycemic load, and body mass index in the Inter 99 study: is underreporting a problem? Am J Clin Nutr. 2006;84:641-5.

[23]Murakami K, Sasaki S, Takahashi Y, Okubo H, Hosoi Y, Horiguchi H, et al. Dietary glycemic index and load in relation to metabolic risk factors in Japanese female farmers with traditional dietary habits. Am J Clin Nutr. 2006;83:1161-9.

[24]Kelley GA, Kelley KS. Effects of aerobic exercise on lipids and lipoproteins in adults with type 2 diabetes: a meta-analysis of randomized-controlled trials. Public Health 2007;121:643-55.

[25]Wing RR, Hill JO. Successful weight loss maintenance. Annu Rev Nutr. 2001;21:323-41.

[26] Saremi A, Shavandi N, Parastesh M, Daneshmand H. Twelve-Week Aerobic Training Decreases Chemerin Level and Improves Cardiometabolic Risk Factors in Overweight and Obesitase Men Asian Journal of Sports Medicine. 2010;1:151-8.

[27]Mattusch F, Dufaux B, Heine O, Mertens I, Rost R. Reduction of the plasma concentration of C-reactive protein following nine months of endurance training. Int J Sports Med. 2000;21:21-4.

[28]Smith JK, Dykes R, Douglas JE, Krishnaswamy K, Berk S. Long-term exercise and atherogenic activity of blood mononuclear cells in persons at risk of developing ischemic heart disease. JAMA.1999;281:1722-7. 